\title{
"A Study on the Benefits of Sustainable Management Practices and its Association with Talent Retention in Star Category Hotels"
}

\author{
Kiran Shende*, Rasika Gumaste ${ }^{\dagger}$ and Gauri Shah
}

\begin{abstract}
Sustainable management encompasses ideas from sustainability and synthesizes them with the concepts of management. This paper focuses on studying the benefits related to sustainable management practices that are adopted and followed in the hotel industry with specific reference to Star Category Hotels of Pune Region and its association with retention of the talented employees in the organisation.

The study had reviewed the practices adopted by star category hotels and its association with retaining the talented bunch of employees. The research design for these factors is then explained further, which is supported by a Chi-Square test as a tool of data interpretation. A structured questionnaire was circulated amongst the managerial level employees in star hotels of the Pune region and responses were collected. The study had revealed that employees do believe that parameters covered under the benefits of the talent retention are mutually beneficial for the organisation as well as the employees.
\end{abstract}

\footnotetext{
AISSMS College of Management \& Catering Technology, Pune; chefkiran1977@gmail.com

† AISSMS College of Management \& Catering Technology, Pune; gumasterasika@gmail.com

‡ AISSMS College of Management \& Catering Technology, Pune; gauristars@gmail.com
} 
Keywords: Sustainable management practices, Sustainability, Talent Retention, Star Hotels, Hospitality Industry, Tourism

\section{Introduction}

Recently a tremendous growth is seen in the Hotel Industry due to its market expansion and business growth. This has resulted in aggressive competition in the hospitality sector. The employees are in demand, have several opportunities of getting jobs and hence the rate of attrition also has gone high. Organisations have been inventing creative strategies to ensure employee satisfaction and retention. Due to the high turnover of people in the hotel industry, retaining valuable employees is a challenge for hoteliers. It is difficult to completely control the turnover of employees, but sustainable human resource management practices will help in resolving this issue.

The three main pillars of sustainability considered in the study are the Environmental (planet) Social (people) and Economic (profit) aspects. The use of sustainability theme is quite broad and comprises of growth or development of employees, organisations, and society - all interlinked with one another in such a way that each one receives a fair and balanced growth opportunity. (Ehnert, 2009)

The important aspect of service delivery is human interaction. The service quality perception, hotel performance and customer satisfaction are impacted by the human resource practices followed by the organisation. The hotel's human resources department makes a conscious effort to keep its employees engaged by using people-centred practices. Thus, the conception of Associate Rendesvous at the workplace has been perceived getting popularity in many hotels. One of the major reasons to quit for the employee could be that he is not been assigned work which motivates and challenges his capacity. The employee should be assigned the work in which he has specialised to utilise his maximum potential. The survival of an organisation will depend upon these talented employees, hence they should be identified and retained at the early stage of their careers in the organisation. An employee delivers a hundred percent when the work interests 
them. The organisation will survive in the competitive environment through the knowledge, skills and attitude of the employees. Organisations survive and succeed through the retention and management of these employees. The employee who spends a more extended term at a specific organisation knows better about the standards, rules and strategies of the hotel and hence can conform better.

\section{Need of the Study}

The increasing market opportunities are a threat to employers as the employees are changing their job at a quicker pace. Today, employees are more motivated to learn, interested in personal development and look for being treated well at work. The hotel's HR department is in the process of developing people-centred practices to keep them with the company for longer periods. Employees remain in the organization when they are satisfied with human resource practices in key areas of their concern. The study examines the human resource practices that organisations use to improve the sustainable employability of their employees and determine their effectiveness towards the organisation. Human resource practices for sustainable employability focus on the longterm goal of contributing to a sustainable career for an employee that is mutually beneficial to the individual and the organisation.

Sustainable employability focuses on retaining employees for long term goals which will help in sustainable careers for the employees, attaining the goal of benefitting the employees as well as the organisations.

Sustainable employability can be measured through Human resource practices like employability, morale and motivation levels of employees and their wellbeing. The present study aims to contribute to both research and practice by emphasising the best human resource practices. The hotel is always on the lookout for developing employee-centric practices that will satisfy the employees leading to job satisfaction and employee engagement. About the options available in the market, the employees will be sustained only if they are satisfied with the practices of their concern. Hence the need of analysing the impact of various 
practices followed by hotels on the retention of employees is understood.

\section{Scope of the Study}

A sustainable business model helps to fulfil and maintain the environmental, societal, or economic aspects as well as to attain the objectives of the organisation. There are many new international brands of a hotel that have entered the Indian market today and are a threat to our hotels. The sustainability aspect helps in gaining a significant advantage over the others in today's competitive scenario. In such situations, it is necessary to design sustainable human resource practices and talent retention programs as a way of building a strong foundation for the organisation. Millennials prefer to work in organizations that follow sustainable Human Resource Practices. Ignoring sustainability in human resource management may lead to a detrimental effect on the organisation. As people are the main driving force for the growth of the organisation, sustainable practices should be given the highest importance. In continuation to this aspect, the study aims to do further investigate the various components of sustainability in human resources and its impact on organisational performance in star category hotels in Pune city.

\section{Literature Review}

Effective Human Resource Practices about Talent retention have been effective for providing excellent service, most consumer pleasure, and worker satisfaction. There are quite a few research, seminars, and articles on the challenge that testify to the significance of worker Genius retention. Hospitality periodicals like Express Hospitality, Hotels and Express, Travel World, etc., are extra vocal with ordinary articles on the above subject.

The inn enterprise developing in leaps and bounds, there is a significant requirement of professional personnel to function the enterprise the demand away exceeds they provide. They want to implement promising and sustainable human aid practices, and its retention is the want of an hour as the Hotel Industry commenced dealing with extraordinary troubles in operations. Effective Human 
Resource Practices about Talent retention have been effective for supplying the best carrier and attaining most client satisfaction.

Attaining the proper intelligence at the proper time will continually be a key centre of attention in the hospitality industry. An Indian market is a location where new accommodations and new manufacturers are getting into higher business. These accommodations' human proper resource branch applies more than a few modern techniques to entice and continue the fantastic Genius of each clean and lateral hire. Kahini Chakraborty, (2015).

Sonali Jadhav \& Santosh Bhave (2013) analysed the most significant trouble about personnel retention in the motel enterprise of Pune city. The lookup displays that the team of workers in the resort enterprise is altering very regularly because the work values and expectations of the personnel nowadays are vastly unique than it was once a decade ago. The survey says that the personnel is searching for information about possibilities and non-public improvement as an alternative to job security. A worker will continue to be in the agency if they are growing abilities and assembly or exceeding their expectations for abilities improvement and boom possibilities; consequently, this lookup is primarily based on the very foundation. The survey says that as there is an increase in many sectors in the town of Pune like IT, Engineering, Automobile, etc. have created a top-notch demand for the hotels, this inn increase has additionally created an incredible demand for the hospitality gurus in the town. As a result, the attrition fee in the town has additionally long gone up. The lodges in the metropolis are struggling for the personnel and discovering extraordinary approaches to continue an employee. They learn about exploring worker advantages as a retention method in the hotel and restaurant industry. The researcher has tried to locate out the hole in an organisation's retention method and the most important motives for the worker's resignation towards what used to be noted through them all through their exit interview. They learn about additionally concludes the significance of the worker retention method in an organisation. While drafting new strategies, companies must analyse the influence it brings along. Employee improvement alongside the organisation's boom helps personnel attain their desires alongside that of the organisation. Recruitment 
and selection, worker engagement, organisational lifestyle and benefits, education, and induction, if planned, would shop the organisational value which is incurred with excessive worker turnover and lack of expert retention Sonal Kumar (2013).

Dr Kalyan Laghane, (2012): Studied retention administration in the Indian hospitality industry. The Results and Observations of the findings recommended that "Talent administration integrates regular talent-related features that had been viewed as "administrative" features into movements' commercial enterprise processes. By entrenching human beings administration methods into modern commercial enterprise techniques, one can pressure line managers to assume recruiting, retention, development, etc., as necessary things to do that make a large contribution to any manager's enterprise effects and success." At the factor when a consultant comprehends that they are required, and they have won the vital potential then, at that point, it is a perfect possibility to make them fulfilled for the preservation or, in all possibility their social gaining knowledge of and scholarly incitement finished, making persons lose income in their positions and start searching someplace else. Thus keeping the proper capacity has constantly been a problem in the cordiality area. The mission of enrolling, preparing, and sharpening palms-on competencies prompts each unmistakable and theoretical misfortune when a beneficial asset leaves the association. (Gurmeet Singh). Absence of accessibility of correct ability, group of workers deficiencies, and uncontrolled poaching have restricted the commercial motel enterprise to take a gander at innovative tactics to preserve folks the work turnover and proficient personnel, the board, is a tough errand for lodges as they cannot proceed to put together new representatives that consist of a parcel of endeavours of the rating personnel and time which several a duration impede the contemporary challenge and stresses the individual, accordingly Vishakha Talreja (2007), the article 'Friendliness brighten up menu to keep ability, discusses gorgeous meals and vacationer solaces remain on the pinnacle of the menu of the cordiality business, the hotels are moreover including spoiled representatives to the rundown. (Region Director of Human Resource, India Subcontinent, Marriott International) as the Market is growing and the world is coming nearer due to the fact of Globalisation, the possibilities request of Hospitality 96 
proficient people is increasing step utilising steps in unique areas like multiplexes, retails chains, global organisations, banks, and different economic associations. it is not easy to preserve proficient representatives as they get a little climb in the CTC and the motivations, they are organised to go away, but this is not the state of affairs with girl representatives as they moreover provide the inclination to work subculture and lodging this was once the grasp with the aid of (Geeta A. Sundrani, Director Oasis Human Resources), she likewise expressed that Preference for friendliness specialists is on growth as prepping and decorum come to be their nature. As per the repute lodgings want a greater distinguished quantity of girl employees contrasted with male representatives. Adding to this, the creator (Ritu S Verma, Regional Director, Human Resources, South Asia - Starwood Hotels and Resorts India) remarks that the lodging moreover has one technique known as 'Starwood Careers Month.' It is set to be a revived augmentation of the fine Starwood Careers Day, the place the lodging celebrates and core round Starwood's distinctiveness that separates the hotel lively individuals, the convincing way of existence brands, having a region with something larger via our affiliation in the networks whereby the motel work and accepting what is going on via the way of existence of advancement. Starwood Careers Month might not be simply a focal point on enrollment but will likewise encompass workout routines spun around capability range and potential vocation improvement and improvement indoors. Worker weakening incredibly is sound and quite appealing as it lets in affiliation supply up the historic and signs up new potential as a long way as abilities, energy, excitement, and enthusiasm. The check is the factor at which the diploma of whittling down crosses enough degrees as some distance as nicely as when it is an outstanding capability that leaves the entryway making consistent loss particularly damaged affecting hierarchical commercial enterprise results. (Ashwin Shirali, Regional Director, Human Resources, Accor Hotels India) expresses that painstakingly specific lengthy haul methodologies should be laboured out to stop these misfortunes and maintain individuals who maintain the way to enterprise persistence and improvement in the assist situated industry. (Zubin Ghiara, Vice President-Human Resources, and Development, Sarovar Hotels and Resorts) facets that the 
protection gadget starts evolved with the enlistment cycle. The hotel ensures that they recruit employees who have confidence in lengthy haul accountability and choose to develop. The company then, at that point, places assets into their studying and improvement via ceaseless getting ready and coaching plans. The team of human asset professionals ensures ceaseless employee dedication drives, setting up a quality job place through representatives in sports, CSR, and different potential primarily based exercises. The motel moreover follows an unmistakably characterised assessment framework linked to an assortment of remuneration and acknowledgement customised. Representatives of all degrees gain from being a reformist, growing association. The associations that provide records about the competencies to teach and do ready jobs at a basic stage give records on anticipated professions for a resort employee engaged with personnel getting ready and willpower of representatives in HR divisions (Druce, Chris (2005).

\section{Research Methodology}

To study the concept of talent retention descriptive research was carried out about various present practices of Talent Retention in Pune hotels. These practices were evaluated with a sustainable growth of the organisation, employees and customers based on surveys and fact-finding enquiries with managerial level hotel employees. The Primary datawas collected from the Manager level employees associated with various hotels in Pune city.

The Primary data was taken using direct Personal Interviews where the respondents agreed for one-to-one interaction. Most of the respondents who could not spare time for such interactions were shared a well-drafted survey sheet and the same was circulated in the form of questionnaires. During the data collection, certain observations that were made over a while also contributed to the research analysis.

A no. of hotels was approached for a personal interview to collect inputs to analyse the research topic. However, considering the excessive workload, shift-based working hours and hesitant respondents; few were available for one-to-one interaction. These respondents were put across a set of pre-conceived questions the 
data was collected in a structured and systematic manner. The questionnaire was drafted carefully and relevant questions concerning the research topic were framed to get the correct inputs and draw suitable conclusions which will aid in analysing the research topic further. The managers were encouraged to share authentic inputs irrespective of any professional views or pressures, data was collected by conducting visits to sample hotels.

The secondary data were collected from published / unpublished literature on sustainable management practices and employee talent retention from the journals, newspapers, research publications and magazines, records and training reports of the hotel, and ample relevant sources available on the internet. The questionnaire design was also carried out with the aid of experts in the field of statistical techniques. The questionnaire was administered according to the population and sample size.

A probability Sampling Technique is used in this study particularly a Multistage Sampling where all the 5-, 4- \& 3-star category hotels were selected at the first stage and later stage the Managerial level employees were selected randomly. A total of 250 questionnaires were distributed out of which 202 responses were received.

\section{Objectives of Research}

- To identify sustainable management practices followed in hotels for talent retention.

- To study the association of sustainable management practices with the benefits of talent retention.

- To compare the Managerial Level Employees based on their Star Category (5-, 4- \& 3-star hotels) with Benefits of talent Retention Management System.

\section{Hypothesis}

\section{Hypothesis - 1}

$\mathrm{H}^{0}$ : There is no significant association between sustainable management practices and talent retention in star hotels.

$\mathrm{H}^{1}$ : There is a significant association between sustainable management practices and talent retention in star hotels. 


\section{Hypothesis - 2}

$\mathrm{H}^{0}$ : There is no significant association between the benefits of talent retention practices and star category hotels.

$\mathrm{H}^{1}$ : There is a significant association between the benefits of talent retention practices and star category hotels.

\section{Data Analysis \& Interpretation}

The collected data were further analysed with advanced analytical tools, which had also included detailed analysis to achieve the set objectives. The analysis is further graphically presented for better understanding and interpretation.

Profile of the Managerial Level Employees

This methodology consists of data collected from the managerial level employees associated with hotels in the city of Pune. The data is entered and analysed as per the category of the respondents; the graph below shows the proportion of the manager respondents. It can be observed that the proportion of managers who responded to the questionnaire was more than $5 \%$ in most of the hotels, whereas few of the hotels had responded below $5 \%$ respectively.

Graph 1: Proportions of the Manager Respondents

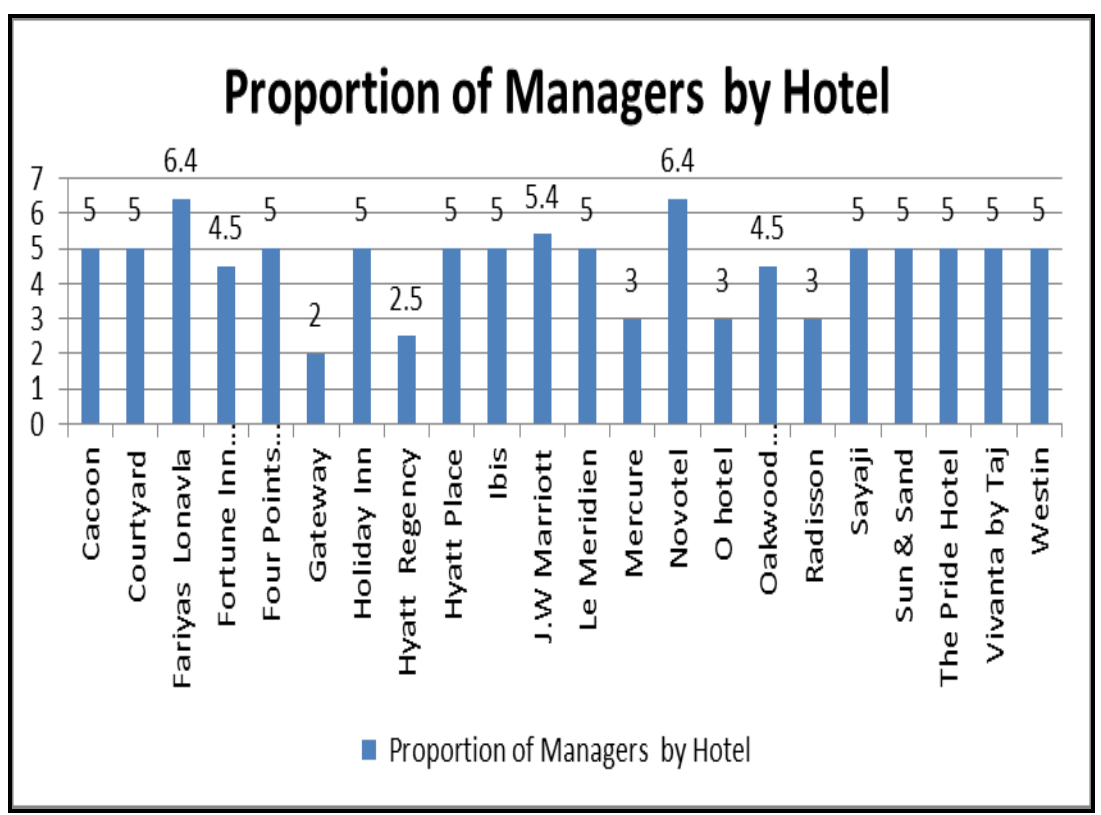


Table and Graph 2: Star Category of the Hotels and percentage of responses received.

\begin{tabular}{lll}
\hline $\begin{array}{l}\text { Catego } \\
\text { ry }\end{array}$ & $\begin{array}{l}\text { Frequen } \\
\text { cy }\end{array}$ \\
\hline 3 stars & 39 & 19.3 \\
\hline 4 stars & 51 & 25.2 \\
\hline 5 stars & 112 & 55.4 \\
\hline Total & 202 & $\mathbf{1 0 0}$ \\
\hline
\end{tabular}

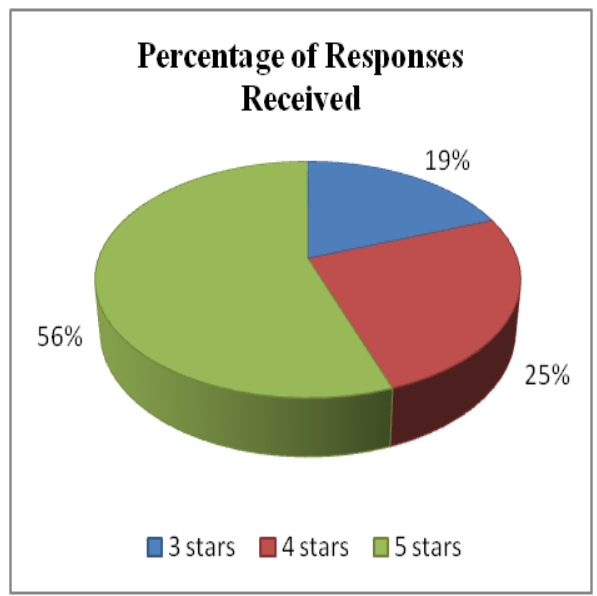

It can be observed from the table and graph that more than $56 \%$ of the hotels included in the study had belonged to the five-star category whereas, this proportion was $25 \%$ for 4 -star category hotels and 19 percent for three-star category hotels, respectively.

Table 3: Frequency Analysis

\begin{tabular}{lllll}
\hline $\begin{array}{l}\text { Sr. } \\
\text { No. }\end{array}$ & Parameter & Agree & Disagree & $\begin{array}{l}\text { Agreement } \\
\%\end{array}$ \\
\hline $\begin{array}{l}\text { It decreases training } \\
\text { and recruitment } \\
\text { operating cost }\end{array}$ & $92 \%$ & $8 \%$ & $100 \%$ \\
\hline 2 & $\begin{array}{l}\text { It motivates } \\
\text { employees to be more } \\
\text { productive }\end{array}$ & $46 \%$ & $100 \%$ \\
\hline 3 & $\begin{array}{l}\text { It increases self- } \\
\text { confidence of the 94\% } \\
\text { employees }\end{array}$ & $6 \%$ & $100 \%$ \\
\hline 4 & $\begin{array}{l}\text { It generates loyalty } \\
\text { towards the hotel } 93 \%\end{array}$ & $7 \%$ & $100 \%$ \\
\hline
\end{tabular}




\section{Observation}

For the parameters covered under the benefits of talent retention, most of the employees agreed upon all the aspects. The retention of talented employees would reduce the training and recruitment expenses incurred by the organisation, which in turn would save upon the operating cost of manpower development. The retention of good and talented employees will certainly benefit the organisation by motivating the employees to be more productive. The appropriate methodology would not only benefit the organisation but also would keep the self-confidence and morale high, additionally, it would also generate employee loyalty towards the organisation.

\section{Inferences}

A good talent retention practice would benefit the organisation in all respect. It would enable an organisation to carry out a systematic workflow in day-to-day operations. It would also benefit an organisation to minimise the operating costs for selection, recruitment, training, and development as these are inversely proportional to each other. The most significant and vital benefit would be increased productivity and self-confidence of the employees, as a confident, happy, and satisfied employee would work with full dedication and always think positive and work for the betterment of the organisation. This would also make an employee more loyal to the organisation.

\section{Cross-Tabulation - Managerial Level Employees}

In this section, the level of agreement between variables for the Benefits of Talent Retention was cross-tabulated with the Star Category. 
Shende et al

A Study on the benefits of sustainable Management

Table 4:

It decreases training and recruitment operating cost

\begin{tabular}{llll}
\hline & Agreed & Disagreed & Total \\
\hline \multirow{3}{*}{3 stars } & 38 & 1 & 39 \\
\cline { 2 - 4 } & $97.4 \%$ & $2.6 \%$ & $100.0 \%$ \\
\hline \multirow{3}{*}{ 5 stars } & 48 & 3 & 51 \\
\cline { 2 - 4 } & $94.1 \%$ & $5.9 \%$ & $100.0 \%$ \\
\hline \multirow{3}{*}{ Total } & 108 & 4 & 112 \\
\cline { 2 - 4 } & $96.4 \%$ & $3.6 \%$ & $100.0 \%$ \\
\hline & 194 & 8 & 202 \\
\hline
\end{tabular}

\section{Chi-Square $-0.740 \mathrm{P}=0.691$}

The chi-square value and $p$-value do not show any association between this particular benefit and the star category of the hotel.

\section{Table 5:}

It motivates employees to be more productive

\begin{tabular}{llll}
\hline & Agreed & Disagreed & Total \\
\hline \multirow{3}{*}{3 stars } & 36 & 3 & 39 \\
\cline { 2 - 4 } & $92.3 \%$ & $7.7 \%$ & $100.0 \%$ \\
\hline \multirow{2}{*}{4 stars } & 48 & 3 & 51 \\
\cline { 2 - 4 } & $94.1 \%$ & $5.9 \%$ & $100.0 \%$ \\
\hline
\end{tabular}




\begin{tabular}{llll}
\hline \multirow{2}{*}{5 stars } & 107 & 5 & 112 \\
\cline { 2 - 4 } & $95.5 \%$ & $4.5 \%$ & $100.0 \%$ \\
\hline \multirow{2}{*}{ Total } & 191 & 11 & 202 \\
\cline { 2 - 4 } & $94.6 \%$ & $5.4 \%$ & $100.0 \%$ \\
\hline
\end{tabular}

Chi-Square $-0.611 \mathrm{P}=0.737$

The chi-square value and p-value do not show any association between this particular benefit and the star category of the hotel.

Table 6:

It increases the self-confidence of the employees

\begin{tabular}{llll}
\hline & Agreed & Disagreed & Total \\
\hline \multirow{3}{*}{3 stars } & 34 & 5 & 39 \\
\cline { 2 - 4 } & $87.2 \%$ & $12.8 \%$ & $100.0 \%$ \\
\hline \multirow{3}{*}{$\mathbf{5}$ stars } & 45 & 6 & 51 \\
\cline { 2 - 4 } & $88.2 \%$ & $11.8 \%$ & $100.0 \%$ \\
\hline \multirow{3}{*}{ Total } & 109 & 3 & 112 \\
\cline { 2 - 4 } & $97.3 \%$ & $2.7 \%$ & $100.0 \%$ \\
\hline
\end{tabular}


Chi-Square -7.084 P= 0.001

A clear variation cannot be seen within the cells of the table, the chi-square value and p-value show an association between this particular benefit and the star category.

\section{Table 7:}

It generates loyalty towards the hotel

\begin{tabular}{llll}
\hline & Agreed & Disagreed & Total \\
\hline \multirow{3}{*}{3 stars } & 33 & 6 & 39 \\
\cline { 2 - 4 } & $84.6 \%$ & $15.4 \%$ & $100.0 \%$ \\
\hline \multirow{3}{*}{ s stars } & 46 & 5 & 51 \\
\cline { 2 - 4 } & $90.2 \%$ & $9.8 \%$ & $100.0 \%$ \\
\hline 5 stars & 95 & 17 & 112 \\
\hline \multirow{2}{*}{ Total } & $84.8 \%$ & $15.2 \%$ & $100.0 \%$ \\
& 174 & 28 & 202 \\
\cline { 2 - 4 } & $86.1 \%$ & $13.9 \%$ & $100.0 \%$
\end{tabular}

\section{Chi-Square $-0.942 \mathrm{P}=0.624$}

Irrespective of the variation, the chi-square value and $p$-value does not show any association between this particular benefit and the star category of the hotel.

Table 8: Chi-square values for Variables tested for the Benefits of talent retention.

\begin{tabular}{|c|c|c|c|}
\hline $\begin{array}{l}\text { Sr. } \\
\text { No }\end{array}$ & Name of the variable & $\begin{array}{l}\text { Chi square } \\
\text { value }\end{array}$ & $\begin{array}{l}\mathrm{P} \\
\text { value }\end{array}$ \\
\hline 1 & $\begin{array}{l}\text { It decreases training and } \\
\text { recruitment operating cost }\end{array}$ & 0.740 & 0.691 \\
\hline
\end{tabular}


2 It motivates employees to be more productive

0.611

0.737

3 It increases the self-confidence of the employees

7.084

0.001

It generates loyalty towards the
hotel

0.942

0.624

Inference: Star category of the hotels establishes the association with the benefits of talent retention. Looking at the above chisquare table it can be inferred that except for increasing selfconfidence of the employees, there is no association in the other benefits of talent retention and the star category therefore null hypothesis was accepted.

\section{Conclusion \& Discussion}

It is observed and found that employees do believe that parameters covered under the benefits of the talent retention are mutually beneficial for the organisation as well as the employees. The retention of talented employees would reduce the unnecessary expenses required for training and recruitment of new employees and in turn, would save upon the operating cost on manpower development made by the organisation. Organisational productivity will increase if good and talented employees are retained by the organisation. Sustainable management practices framed towards talent retention would benefit the organisation by keeping the employee morale high and boosting their selfconfidence. Retention of old, long term employees results in an increased no. of loyal employees in the organisation. Sustainable management practices would benefit the organisation in all respect. It also enables an organisation to carry out a systematic workflow in day-to-day operations. An effective Sustainable management practice leads to job satisfaction and enables good retention. The Star category of the hotels also has an association with the sustainable benefits of talent retention practices with specific reference to boosting the self-confidence of the employees. The Star category of the hotels does not have an association with the 106 
sustainable benefits of talent retention practices like reducing training and recruitment operating costs, employee motivation and employee loyalty in the hotel. Hotels should frame sustainable talent retention practices for engaging their employees and retaining them. This could be done through conducting timely reviews amongst the Hotel staff and Management.

Hotels should focus on gathering information about employees' interests as well as distress. Hotels should develop a mechanism to identify talented employees early and work towards developing them for the future, so they end up being an asset to the organisation. Hotels could work upon techniques to keep employees motivated and increase their job satisfaction. A sense of responsibility could be generated by empowering the employees that would generate loyalty towards the organisation. The Hotel Management should schedule timely interactions with the employees to understand their mindset, needs and expectations. Hotel employees are looking forward to sustainable management practices and are happy to be retained in organizations that offer them good benefits. Sustainable management practices boost the self-confidence of employees and help in retaining them in the organisation. The hotel organisations have an effective Human Resource Management system in place, and they are striving to identify methods of making the practices more sustainable. This could be confirmed from the responses received after personal interaction, through survey questioners and by way of observations while conducting the research analysis. Hence, we conclude that Sustainable Talent Retention practices are the new mantra for the wholesome growth of an employee as well as the hotel organisation. However, a continuous review of market trends, practices and employee expectations is required for the sustainability of human resource practice. Such timely review and timely up-gradation and correction are possible only with the help of continuous interactions between stakeholders and the organisation.

\section{Significance and Limitations}

To retain talented employees, the HRD have to frame innovative practices for retention. This would motivate employees to be 
focused on their respective tasks and also build generate loyalty. For example, employee poaching which happens rampantly these days partially can be used to explain why Human Resource Management has an important role to play in organisational growth. Sustainable Human Resource Management is concerned with the use of those practices which help to develop human and social capital within the organisation. Few organisations could link HR practice and sustainability together, but there are limitations of literature and framework explaining the successful implementation of sustainable practices in HRM thus study is significant.

The study had aimed to learn sustainable management practices adopted by star category hotels which help in enhancing employee productivity, employee motivation, recruitment, training, and loyalty towards the hotel and its association with retaining the employees. The study was carried out purely on information shared by respondents and according to the current trends, ideas and judgements, it may vary with time and location. The study does not differentiate between respondents according to their location that would influence their response, thereby scope for further research.

\section{References}

Aishwarya Mudaliar (2008), Training for retention, Beyond human and social capital, Business Horizons, expresshospitality.com, March 1-15, 200847/1, JanuaryFebruary 2004 (45-50).

Chris (2005), Career clinic, Caterer \& Hotelkeeper, 2/10/2005, Vol. 194, Issue 4361, p. 60-60.1/3p, ISSN 0008-7777

Chang Way, (2010), Individual employment characteristics of hotel employees that play a role in employee satisfaction and work retention, International Journal of Hospitality Management. Sep 2010, Vol. 29, Issue 3, p. 344-353. 10p.

David Mc Millin, (2013), the Secret to Improving Employee Retention in the Hospitality Industry, April 29, 2013.

Dr Kalyan Laghane, (2012): “A Study of Retention Management in Indian Hospitality Industry: A Practical Viewpoint", Excel 
Journal of Engineering Technology and Management Science (An International Multidisciplinary Journal Vol. I No. 2 January - June 2012, ISSN 2277-3339.

Dr Sonali Jadhav (2013), "Training and development for effective employee retention in the hotel industry", Pune, Tactful Management Research Journal, Volume 2, Issue 3, Dec 2013, ISSN - 2319-7943.

Druce, (2005), Career clinic, Caterer \& Hotelkeeper, 2/10/2005, Vol. 194, Issue 4361, p. 60-60.1/3p. ISSN 0008-7777.

Employee Stock Ownership Plan - ESOP (2007): Paving hospitality growth Express Hospitality October 16 - 31, 2007, Page No. 58-59.

Edition 1st, First Published 2007, eBook Published 22 October 2007, Pub. Location New York Imprint Routledge https://doi.org/10.4324/9780203820650

Goswami Brijesh Kishor(2012), Attrition issues and Retention Challenges of Employees. International Journal of Scientific \& Engineering Research, Volume 3, Issue 4, April 2012.p.15.

Kelly (2010), mentioned in the article Individual employment characteristics of hotel employees that play a role in employee satisfaction and work retention, International Journal of Hospitality Management. Sep 2010, Vol. 29, Issue 3, p. 344-353. 10p.

Lee (2010) article on Individual employment characteristics of hotel employees that play a role in employee satisfaction and work retention, International Journal of Hospitality Management. Sep 2010, Vol. 29, Issue 3, p. 344-353. 10p.

Lockyer, T. L. G. (2007), stated in the article The International Hotel Industry: Sustainable Management.

Luthans, F., (2004) Positive psychological capital journal, digitalcommons.unl.edu, with the rising recognition of human resources as a competitive advantage in today's global economy, human capital

Luthans, K. W., (2004) Positive psychological capital journal, digitalcommons.unl.edu, With the rising recognition of 
human resources as a competitive advantage in today's globaleconomy, human capital

Luthans, B. C. (2004) Positive psychological capital journal, digitalcommons.unl.edu, With the rising recognition of human resources as a competitive advantage in today's globaleconomy, human capital

Luthans F, (2004). Human, social, and now positive psychological capital management. Organizational Dynamics, 33, 143-160

News track (2007) ESOP blues strike hotels Express hospitality, 1631 March.

Paul Honey (2009), Make it simple for employees to say yes, Hotel and Motel Management, Vol. 224, No. 8, July 2009

Rao Sabita (2007), Talent Retention Strategies in a Competitive Environment, NHRD Journal, May 2007, p. 30-32.

Ruth Mayhew (2015), The Challenge of Talent Retention, July 20, http://www.financialexpress.com/article The Haworth Press, Inc., Demand Media.

Santosh Bhave (2013), "Training and development for effective employee retention in the hotel industry", Pune, Tactful Management Research Journal, Volume 2, Issue 3, Dec 2013, ISSN - 2319-7943.

Sushmita Jha, (2012), wrote in the Attrition issues and Retention Challenges of Employees. International Journal of Scientific \& Engineering Research Volume 3, Issue 4, April 2012. p.1-5

Sonal Kumar (2013), “The impact of employee benefits as retention strategy in a concept dining restaurant chain in India", Dissertation, The National College of Ireland, September 2013.

Sophia Araba Twum (2015), “What diversity management practices do hotel managers and employees view as important for retaining employees? Thesis, faculty of social sciences, Norwegian school of hotel management 2015.

Staff Writer, (2013), the Secret to Improving Employee Retention in the Hospitality Industry, April 29, 2013. 
Tom Newcombe, (2013) Hospitality and tourism employers should focus on staff retention to improve productivity, says report MARCH 22, 2013, http:/ / www.hrmagazine.co.uk/article

Timothy Lockyer (2007) The International Hotel Industry, Sustainable Management

Vishakha Talreja (2007), TNN Hospitality spices up menu to retain talent Apr 4, 2007

(http:/ / articles.economictimes.indiatimes.com/2007-0404/news/28418909_1_park-hotels- hotel-industry-Bharathotels)

Yashoda Jadhav (2008), “Empowering the Commons", Hospitality biz, Vol 1, Issue 39, Dec 08-14, 2008, pg. 15 - 16.

Youssef C M. (2004). Human, social, and now positive psychological capital management. Organizational Dynamics, 33, 143-160.

WajdaWikhamn, (2019) article on Sustainable HRM helpsinnovation and can make hotel guests happier, 18 February 2019. 